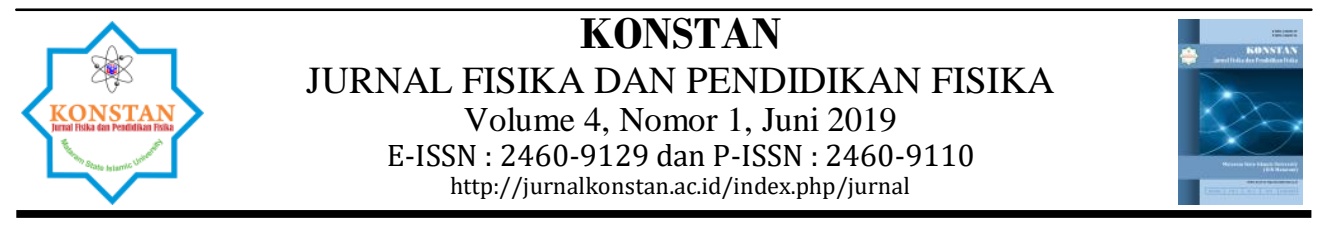

\title{
ANALISIS KADAR AIR DALAM MADU MENGGUNAKAN KOMBINASI METODE KAPASITANSI DAN INDEKS BIAS
}

\author{
N.K. Indah Swari ${ }^{1}$, Rahadi Wirawan $^{1 *}$, Nurul Qomariyah ${ }^{1}$, Kasnawi Al Hadi $^{1}$ \\ ${ }^{1}$ Program Studi Fisika, FMIPA, Universitas Mataram, Jl. Majapahit No. 62, Mataram, \\ Indonesia
}

\section{Info Artikel \\ Sejarah Artikel: \\ Diterima November 2018 \\ Disetujui Juni 2019 \\ Dipublikasikan Juni 2019}

\section{Kata Kunci:}

Madu, kapasitansi,

konstanta dielektrik, indeks

bias, kadar air

\begin{abstract}
Abstrak
Telah dilakukan penelitian analisis kadar air madu menggunakan kombinasi metode kapasitansi dan indeks bias. Penelitian ini bertujuan untuk mengetahui hubungan konstanta dielektrik dan indeks bias terhadap kadar air dalam madu berdasarkan Standar Nasional Indonesia (SNI) 013545-2004. Pada penelitian dilakukan 5 variasi penambahan air $(0,2,5 \mathrm{ml}, 5 \mathrm{ml}, 7,5 \mathrm{ml}$ dan $10 \mathrm{ml})$ untuk setiap sampel madu Sumbawa, madu Trigona dan madu kemasan. Hasil interpretasi data menunjukkan bahwa semakin besar nilai konstanta dielektrik madu mengindikasikan semakin rendah kadar air dalam madu dan semakin rendah nilai indeks bias madu menunjukkan kadar air dalam madu semakin besar. Selain itu juga, kadar air dalam madu kemasan dan madu Sumbawa berada dalam rentang kadar air yang disyaratkan SNI $(<22 \%)$ berdasarkan nilai indeks bias sementara untuk madu Trigona tidak berada dalam rentang tersebut.
\end{abstract}

\footnotetext{
* Corresponding Author: rwirawan@unram.ac.id
}

Alamat korespodensi:

Program Studi Fisika, Fakultas Matematika dan Ilmu Pengetahuan Alam, Universitas Mataram, Jl. Majapahit No. 62 Mataram 83125, Mataram, Indonesia

Email: rwirawan@unram.ac.id 


\section{PENDAHULUAN}

Madu merupakan cairan kental manis hasil produksi lebah madu dengan bahan dasar yang bersumber dari nektar bunga. Madu terdiri dari campuran kompleks $82,0 \%$ karbohidrat (sukrosa, fruktosa, maltosa), 0,3\% protein, 17,0\% air dan antioksidan. Selain gula, madu juga mengandung vitamin B kompleks, vitamin $\mathrm{C}$ dan berbagai macam mineral [1]. Indeks bias madu cukup tinggi sebesar 1,5 dengan berat jenis 1,4 dan $\mathrm{pH}$ rata-rata 4 [2]. Madu banyak dimanfaatkan sebagai sumber nutrisi dan pengobatan di bidang kesehatan dimana madu memiliki kandungan energi sebesar $3.280 \mathrm{kal} / \mathrm{gr}$, dan mengandung nutraceuticals yang efektif menghilangkan radikal bebas dari tubuh manusia [3]. Selain itu, madu memiliki kemampuan meningkatkan kecepatan pertumbuhan jaringan baru [4], dan dapat mengendalikan pertumbuhan bakteri [5], serta meningkatkan antioksidan plasma [6]. Di pasaran banyak dijumpai berbagai jenis madu kemasan maupun madu lokal seperti halnya madu Sumbawa dan madu Trigona dengan kualitas dan karakteristik yang berbeda-beda. Tindakan pemalsuan kemurnian madu yang sengaja dilakukan maupun proses penyimpanan yang kurang baik dapat menyebabkan penurunan kualitas madu. Oleh karena itu, monitoring pengujian kualitas sangat penting dilakukan guna menjaga agar madu memenuhi standar mutu yang diijinkan.

Salah satu parameter yang menentukan kualitas suatu jenis madu adalah kadar air selain kadar keasamaan, gula pereduksi, dan kandungan sukrosa. Kadar air dalam madu dipengaruhi oleh kelembaban lingkungan dimana semakin tinggi kelembaban menyebabkan kadar air dalam madu akan semakin tinggi. Kadar air yang tinggi dapat memicu pertumbuhan dan berkembangnya khamir [7]. Oleh karenanya, badan standar mutu nasional mensyaratkan kadar air yang diijinkan berdasarkan SNI 01-3545-2004 tidak boleh melebihi batas 22\% [8].

Air merupakan salah satu material dielektrik sementara madu memiliki sifat higroskopis atau mudah menyerap air. Keberadaan air dalam madu akan mempengaruhi sifat dielektriknya. Oleh karena itu, penentuan kadar air dalam madu dapat dilakukan menggunakan metode kapasitasi yaitu melalui pengukuran nilai konstanta dielektrik. Metode ini telah diaplikasikan untuk mengevaluasi aktivitas dan pertumbuhan akar dimana kandungan air tanah sangat mempengaruhi hasil pengukuran [9], penentuan konstanta dielektrik minyak cengkeh [10]. Selain metode kapasitansi, metode pengukuran indeks bias (refraction index) juga dapat digunakan untuk menentukan kadar air dalam madu. Air berperan sebagai pelarut dalam suatu larutan, keberadaan air akan mempengaruhi densitas larutan yang secara signifikan akan memberikan pengaruh pada sifat optis larutan yaitu indeks bias [11]. Metode ini telah berhasil diaplikasikan pada pengukuran kadar air dalam minyak cengkeh [10]. Dalam tulisan ini, dipaparkan analisis kadar air dalam madu berdasarkan nilai konstanta dielektrik dan nilai indeks biasnya. Jenis madu yang dianalisis adalah madu kemasan, madu Sumbawa dan madu Trigona.

\section{METODE PENELITIAN}

Penelitian ini terdiri atas beberapa tahapan antara lain perancangan sistem instrumentasi, kalibrasi alat, pengambilan data, pengolahan dan interpretasi data. Pengambilan data dilakukan melalui pengukuran nilai kapasitansi dan nilai indeks bias sampel madu. Kapasitansi merupakan suatu nilai yang menyatakan kemampuan suatu bahan menyimpan muatan listrik. Dalam penelitian ini, pengukuran nilai 
kapasitansi dilakukan dengan menggunakan model kapasitor plat sejajar yang tersusun oleh dua buah keping plat konduktor yang dipisahkan pada jarak tertentu (Gambar 1a). Besarnya nilai kapasitansi kapasitor tersebut ditentukan menggunakan formulasi berikut [12].

$$
C_{0}=\frac{\varepsilon_{0} A}{d}
$$

dimana $A$ adalah luasan plat sejajar, $d$ adalah jarak antara plat dan $\varepsilon_{0}$ adalah permitivitas listrik ruang hampa.

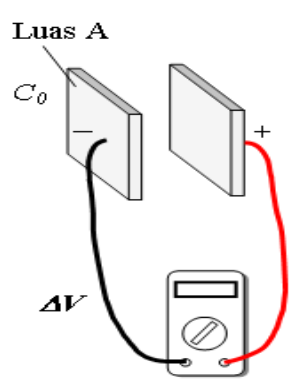

(a)

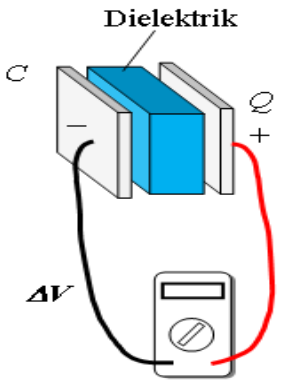

(b)

Gambar 1. Sebuah Kapasitor yang Diberi Muatan (a) tanpa dielektrik dan (b) adanya bahan dielektrik diantara kedua kepingnya [12].

Keberadaan suatu bahan dielektrik diantara kedua plat kapasitor (Gambar 1b) menyebabkan adanya perubahan nilai kapasitansi kapasitor. Besarnya perubahan nilai tersebut sebanding dengan konstanta dielektrik $\kappa$ seperti diungkapkan melalui formulasi [12].

$$
C=\kappa \frac{\varepsilon_{0} A}{d}
$$

Pada penelitian ini, bahan yang ditempatkan diantara kedua pelat tersebut adalah sampel madu. Pengukuran nilai kapasitansi dilakukan menggunakan kapasitansi meter tipe CM8601 A+ dengan susunan peralatan seperti ditampilkan pada Gambar 2a. Wadah sampel madu terbuat dari plat akrilik, dimana plat akrilik tersebut juga bertindak sebagai bahan dielektrik. Keberadaan akrilik tersebut diperhitungkan sebagai susunan seri kapasitor (Gambar 2b). Kombinasi kapasitor seri digunakan untuk mengetahui pengaruh akrilik terhadap pengukuran kapasitansi kapasitor dan kapasitansi udara.

Pada tahap selanjutnya dilakukan pengukuran indeks bias madu yang merupakan parameter optik. Indeks bias menyatakan kemampuan cahaya merambat dalam suatu bahan berdasarkan keberadaan molekul-molekul penyusunnya. Indeks bias $(n)$ dinyatakan sebagai rasio antara kelajuan cahaya dalam ruang hampa $(c)$ udara terhadap kelajuan cahaya dalam suatu bahan $(v)$ seperti diungkapkan melalui persamaan (3) berikut. 


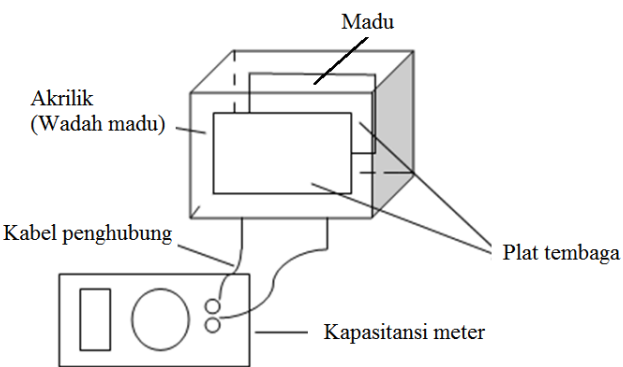

(a)

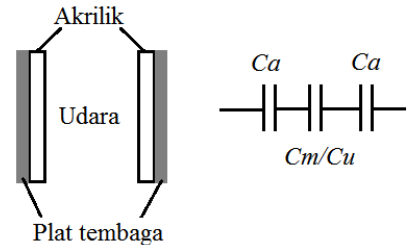

(b)

Gambar 2. Skematik Susunan Peralatan

$$
n=\frac{c}{v}
$$

Adapun besarnya nilai indeks bias tersebut sangat bergantung pada parameter densitas medium $(\rho)$, berat molekul $(W)$ dan refraktivitas molar $\left(A_{m}\right)$ yang diungkapkan dalam formulasi Lorentz-Lorentz berikut [11].

$$
\frac{n^{2}-1}{n^{2}+2} \frac{W}{\rho}=A_{m}
$$

Selain itu, indek bias juga memiliki keterkaitan dengan parameter konstanta dielektrik ( $\kappa)$ yang diungkapkan dalam hubungan [13].

$$
n=(\kappa)^{1 / 2}
$$

Pengukuran nilai indeks bias madu dilakukan untuk 5 variasi penambahan volume air yaitu $0,2,5 \mathrm{ml}, 5 \mathrm{ml}, 7,5 \mathrm{ml}$ dan $10 \mathrm{ml}$ dengan volume total larutan madu $20 \mathrm{ml}$. Peralatan yang digunakan dalam pengukuran nilai indeks bias adalah Reffraktometer Abbe.

\section{HASIL DAN PEMBAHASAN}

\section{A. Kalibrasi}

Kalibrasi dilakukan dalam penentuan indeks bias udara. Dalam menentukan indeks bias udara, kapasitansi kapasitor didasarkan sebagai rangkaian seri kapasitor seperti tampak pada Gambar 3. Pengukuran nilai kapasitansi akrilik diperoleh $10 \mathrm{pF}$ dan nilai konstanta dielektrik $\left(\kappa_{A}\right)$ 2,831. Sementara itu, hasil pengukuran kapasitansi kapasitor $\left(\mathrm{C}_{\mathrm{p}}\right)$ dibandingkan dengan perhitungan teoritis $\left(C_{\mathrm{T}}\right)$ ditampilkan pada Tabel 1.

Berdasarkan hasil perhitungan kapasistansi udara menggunakan rangkaian seri kapasitor akrilik-udara-akrilik diperoleh sebesar 41,933 pF dengan indeks bias udara $\left(n_{u}\right)$ sebesar 1. Sementara itu hasil pengukuran dengan 5 perulangan (Tabel 2) diperoleh indeks bias udara pengukuran $\left(n_{u p}\right)$ sebesar 1,047 dengan error 4,681\%. 
Tabel 1. Hasil Pengukuran Kapasitansi Kapasitor

\begin{tabular}{ccccc}
\hline No. & $\begin{array}{c}\boldsymbol{C}_{\mathbf{T}} \\
(\mathbf{p F})\end{array}$ & $\begin{array}{c}\boldsymbol{C}_{\mathbf{p}} \\
(\mathbf{p F})\end{array}$ & $\begin{array}{c}\left|\boldsymbol{C}_{\mathbf{T}}-\boldsymbol{C}_{\mathbf{p}}\right| \\
(\mathbf{p F})\end{array}$ & $\begin{array}{c}\text { Error } \\
(\mathbf{\%})\end{array}$ \\
\hline 1 & 24,573 & 25,900 & 1,327 & 5,4 \\
\hline 2 & 24,573 & 25,900 & 1,327 & 5,4 \\
\hline 3 & 24,573 & 25,900 & 1,327 & 5,4 \\
\hline 4 & 24,573 & 25,900 & 1,327 & 5,4 \\
\hline 5 & 24,573 & 25,900 & 1,327 & 5,4 \\
\hline
\end{tabular}

Tabel 2. Hasil Pengukuran Indeks Bias Udara

\begin{tabular}{ccccc}
\hline No. & $\begin{array}{c}\boldsymbol{C}_{\mathbf{U p}} \\
(\mathbf{p F})\end{array}$ & $\boldsymbol{n}_{\mathrm{Up}}$ & $\boldsymbol{n}_{\mathbf{U P}}$ & $\begin{array}{c}\text { Error } \boldsymbol{n}_{\mathbf{U}} \\
(\boldsymbol{\%})\end{array}$ \\
\hline 1 & 45,950 & 1,047 & 1,000 & 4,681 \\
\hline 2 & 45,950 & 1,047 & 1,000 & 4,681 \\
\hline 3 & 45,950 & 1,047 & 1,000 & 4,681 \\
\hline 4 & 45,950 & 1,047 & 1,000 & 4,681 \\
\hline 5 & 45,950 & 1,047 & 1,000 & 4,681 \\
\hline
\end{tabular}

Kalibrasi refraktometer dilakukan untuk mengetahui keakuratan refraktometer dalam membaca indeks bias. Pembacaan indeks bias air menggunakan refraktometer $\left(n_{\mathrm{aP}}\right)$ menunjukkan nilai yang sesuai dengan indeks bias air secara teori $\left(n_{\mathrm{aT}}\right)$ yaitu 1,333 dan berdasarkan hasil tersebut dapat dilakukan tahapan pengambilan data kapasitansi kapasitor dan indeks bias madu.

\section{B. Analisis Konstanta Dielektrik Madu}

Saat suatu bahan dielektrik seperti halnya madu dimasukkan di antara keping-keping kapasitor, kapasitansi kapasitor meningkat sebesar faktor $\kappa$ yang merupakan konstanta dielektrik madu. Kapasitansi awal kapasitor adalah 24,573 pF sedangkan nilai kapasitansi kapasitor setelah dimasukkan madu di antara kepingkepingnya mengalami peningkatan yang bervariasi untuk ketiga jenis madu. Pada Gambar 3 dapat dilihat bahwa kapasitansi tertinggi diperoleh tanpa perlakuan penambahan volume air $(\mathrm{Va})$ sedangkan kapasitansi terendah diperoleh saat dilakukan penambahan volume air sebanyak $10 \mathrm{ml}$.

Polarisasi muatan yang terjadi pada dielektrik (madu) menimbulkan medan listrik internal yang menyebabkan pengurangan medan listrik efektifnya (resultan medan listrik). Pengurangan medan listrik efektif ini berdampak pada nilai konstanta dielektrik menjadi lebih tinggi. Berdasarkan Gambar 3 diketahui bahwa semakin besarnya penambahan volume air pada madu menyebabkan nilai kapasitansi mengalami penurunan, hal ini terjadi karena air bersifat sebagai molekul polar. Molekul polar memiliki arah yang acak ketika tidak ada medan eksternal yang mempengaruhinya. Saat terdapat medan eksternal akibat muatan kapasitor, molekul-molekul akan menjadi lebih searah dengan medan listriknya sehingga 
meningkatkan medan listriknya dan mengakibatkan kapasitansi kapasitor mengalami penurunan.

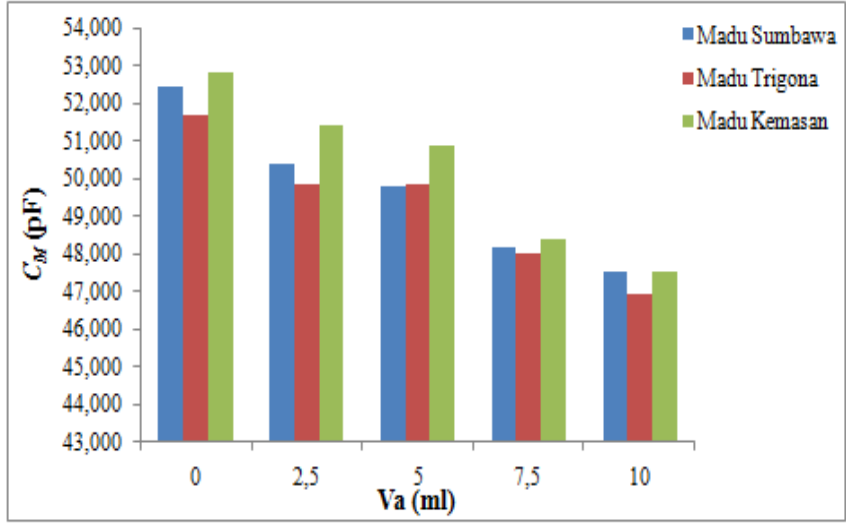

Gambar 3. Perbandingan Penambahan Volume Air dalam Madu Terhadap Kapasitansi Kapasitor

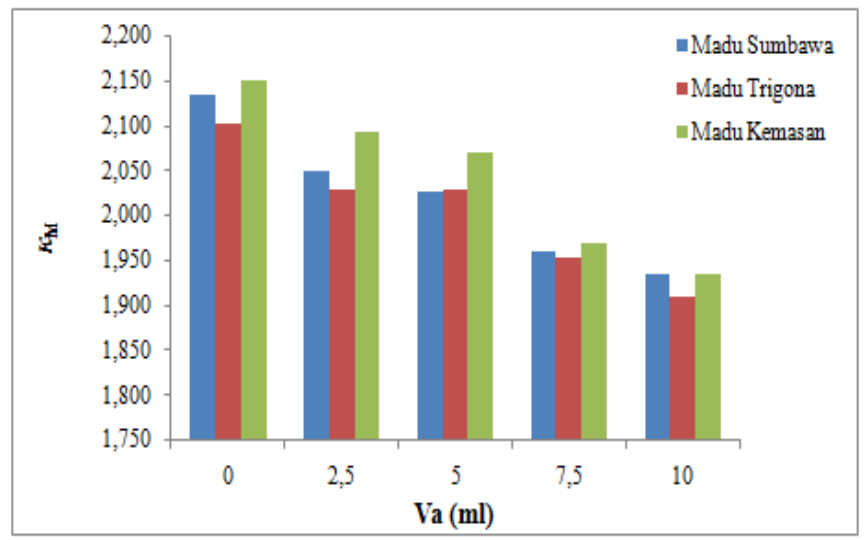

Gambar 4. Konstanta Dielektrik Akibat Penambahan Volume Air Pada Madu

\section{Analisis Indeks Bias Madu}

Indeks bias madu diperoleh dari konstanta dielektriknya berdasarkan hubungan persamaan (5). Setiap variasi penambahan volume air pada madu menghasilkan penurunan pada indeks biasnya (Gambar 5). Semakin besar penambahan volume air menyebabkan kerapatan antar molekul pada madu menjadi lebih rendah yang ditandai dengan semakin cair madu tersebut sehingga sinar yang mengenai madu mudah untuk dibiaskan saat dilakukan pengukuran menggunakan refraktometer. Semakin mudah sinar dibiaskan menyebabkan indeks bias madu semakin rendah. Hal ini terjadi karena sifat air yang mudah membiaskan cahaya. Sebaliknya, semakin rendah penambahan volume air pada madu menyebabkan kerapatan antar molekul madu menjadi lebih tinggi yang ditandai dengan semakin kental madu tersebut sehingga sinar yang mengenai madu lebih sulit untuk dibiaskan dan menyebabkan indeks biasnya tinggi. 




Gambar 5. Perbandingan Variasi Penambahan Volume Air Terhadap Indeks Bias Madu

Hasil tersebut menunjukkan bahwa kerapatan medium (larutan madu) memberikan pengaruh yang signifikan terhadap nilai indeks bias larutan madu. Hal ini sesuai dengan yang diungkapkan oleh Jonasz dan Fournier (2007) bahwa densitas medium, berat molekul dan refraktivitas molar adalah parameterparameter yang mempengaruhi nilai indeks bias [13].

\section{Hubungan Indeks Bias terhadap Kadar Air Dalam Madu}

Indeks bias madu dalam penelitian ini ditentukan menggunakan dua metode yaitu menggunakan pengukuran indeks bias dengan Refraktometer Abbe dan menggunakan kapasitor. Penentuan indeks bias udara berdasarkan nilai kapasitansi kapasitor ditentukan menggunakan persamaan (5). Setelah dilakukan tahapan analisis data diperoleh kadar air dalam madu ditampilkan pada Gambar 6-8 berikut.

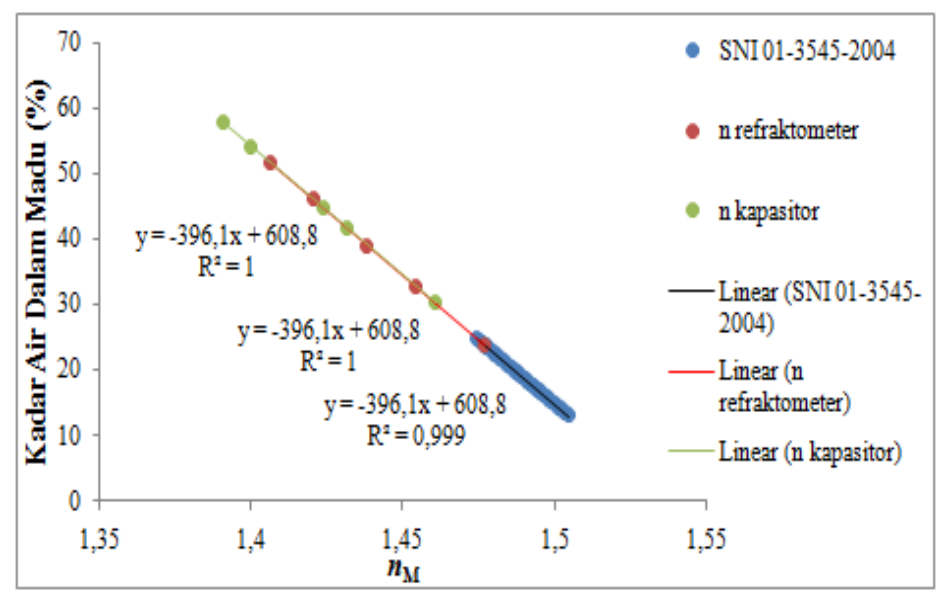

Gambar 6. Hubungan Indeks Bias Terhadap Kadar Air Dalam Madu Sumbawa 


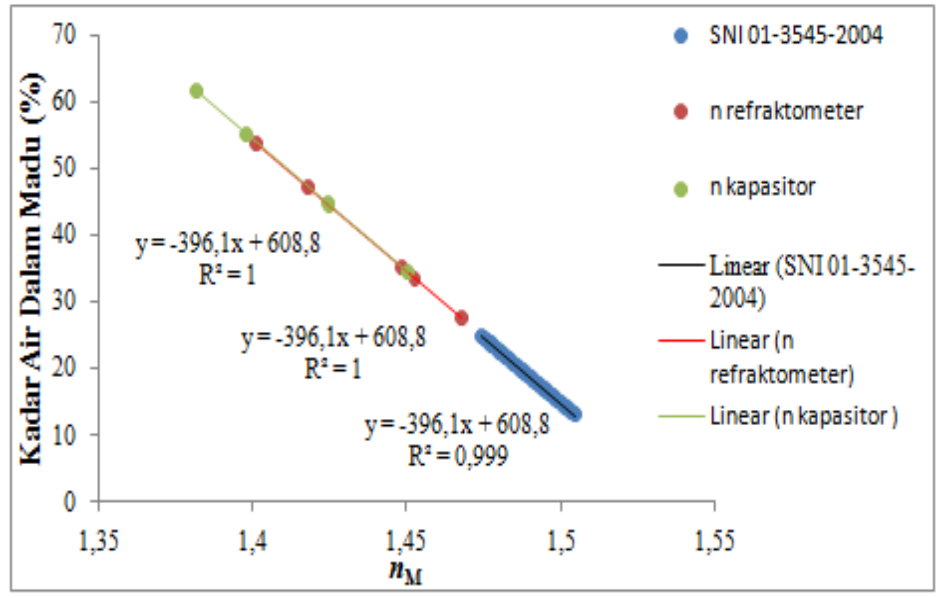

Gambar 7. Hubungan Indeks Bias Terhadap Kadar Air Dalam Madu Trigona

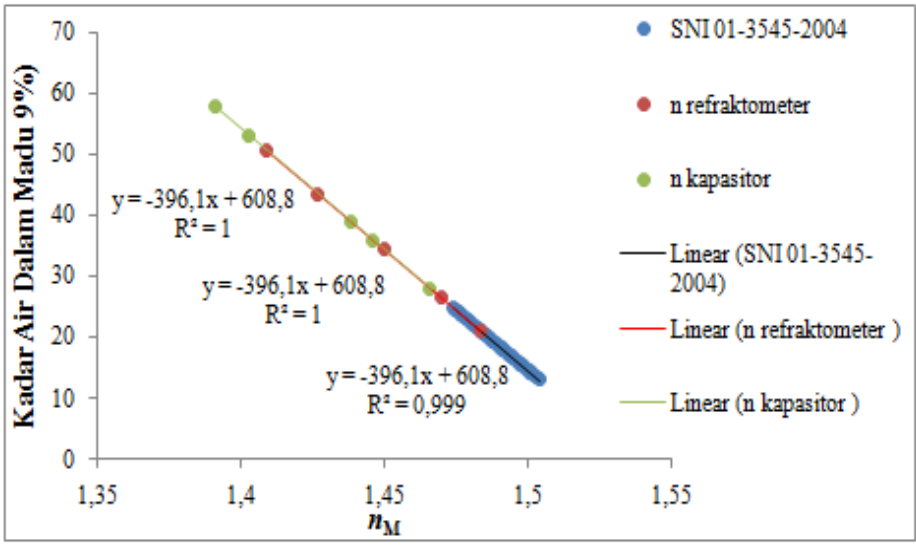

Gambar 8. Hubungan Indeks Bias Terhadap Kadar Air Dalam Madu Kemasan

Madu yang berkualitas baik memiliki kadar air yang rendah yang mengindikasikan bahwa madu yang lebih kental memiliki kadar air dalam madu yang lebih rendah. Berdasarkan grafik (Gambar 6-8) diperoleh bahwa kadar air dalam madu berbanding terbalik dengan indeks bias yang dimilikinya. Semakin besar indeks biasnya semakin rendah kadar air yang terkandung dalam madu tersebut begitu juga sebaliknya. Hubungan antara keduanya dapat diungkapkan dalam persamaan garis linier $y=-396,1 x+608,8$ dengan variabel $x$ adalah indeks bias madu dan variabel y menyatakan kadar air dalam madu.

Hasil pengukuran indeks bias madu menggunakan refraktometer menunjukkan bahwa madu kemasan dan madu Sumbawa berada dalam rentang kadar air yang sesuai dengan SNI yaitu dibawah 22\%. Sementara itu berdasarkan perhitungan menggunakan hubungan konstanta dielektrik dan indeks bias diperoleh bahwa kadar air dalam madu kemasan, madu sumbawa dan madu trigona tidak berada dalam rentang yang disyaratkan dalam SNI. Adapun perbedaan hasil ini diakibatkan kapasitor yang dibuat memiliki error pengukuran kapasitansi sebesar $5,4 \%$. Nilai error ini mengakibatkan pergeseran nilai kadar air yang cukup 
signifikan sehingga perlu dikembangkan suatu metode pengukuran untuk mereduksi error tersebut.

\section{SIMPULAN DAN SARAN}

Kadar air dalam madu dapat ditentukan berdasarkan kombinasi karakteristik kelistrikan dan optiknya, yaitu hubungan antara parameter konstanta dielektrik dan indeks bias dengan kadar air. Semakin tinggi kadar air dalam madu, nilai konstanta dielektrik semakin rendah dan begitu pula halnya dengan nilai indeks bias yang semakin kecil.

\section{DAFTAR PUSTAKA}

[1] Codex Alimentarius Commission. 2001. Codex Standard for Honey, Standards and Standard Methods. Roma.

[2] Amabye TG, Mekonen F. 2016. Phytochemical and Biochemical Composition of Wild Honey A Case Study in Eastern Zone Areas in Tigray Ethiopia. Journal of Nutritional Health \& Food Engineering, 4(4): 00141. DOI: 10.15406/jnhfe.2016.04.00141, p1-6.

[3] Muhamad, F. S. 2012. Madu dan Khasiatnya : Suplemen Sehat Tanpa Efek Samping. Yogyakarta: Diandra Pustaka Indonesia.

[4] Wineri, Esi, Rasyid, R., Alioes, Y. 2014. Perbandingan Daya Hambat Madu Alami dengan Madu Kemasan secara In Vitro terhadap Streptococcus beta hemoliticus Group A sebagai Penyebab Faringitis. Sumatera Barat: Universitas Andalas.

[5] Alvarez-Suarez, J.M., et al. 2014. The Composition and Biological Activity of Honey: A Focus on Manuka Honey. Foods 2014, 3, doi:10.3390/foods3030420, p. 420-432.

[6] Asaduzzaman, M, et al. 2015. Analysis of Biochemical Composition of Honey and Its Anti-Oxidant, Phytochemical and Anti-Bacterial Properties. Amerika: American Chemical Society.

[7] Dyah, D. W. 2017. Kualitas Madu (Keasaman, Kadar Air dan Kadar Gula Pereduksi) Berdasarkan Perbedaan Suhu Penyimpanan. Surabaya: Universitas Nahdlatul Ulama.

[8] Badan Standar Nasional Indonesia SNI 01-3545-2004, https://www.slideshare.net/Fitrijasmineandriani/sni-01-35452004-madu yang diakses pada 3 Mei 2018 10.08 WITA.

[9] Cseresnyés, I., et al. 2018. Application of Electrical Capacitance Method for Prediction of Plant Root Mass and Activity in Field-Grown Crops. Frontiers in Plant Science, 9 (93) doi: 10.3389/fpls.2018.00093, p. 1-11.

[10] Budiarti, D.D. 2015. Penentuan Indeks Bias dan Konstanta Dielektrik Minyak Cengkeh (Clove Oil). Jawa Timur: Fakultas MIPA Universitas Jember.

[11] Jonasz, M. \& Fournier, G., R. 2007. Light Scattering by Particles in Water Theoretical and Experimental Foundations, USA: Elsevier.

[12] Serway, J. 2010. Fisika untuk Sains dan Teknik. Jakarta : Salemba Teknika. 
N. K. Indah Swari dkא/KONSTAN Volume 4, Nomor 1 Halaman 1-10

[13] Fowles, G.R. 1989. Introduction to Modern Optics Second Edition. New York: Dover Publication Inc. 